\title{
Ince Film Üretiminde Kimyasal Buhar Biriktirme Yöntemi ve Çeşitleri
}

\author{
Ayşegül ÇOŞĞUN (iD) 1*, Ayşegül TAŞÇIOĞLU (iD2, Gökhan YILMAZ iD 3 \\ ${ }^{1}$ Burdur Mehmet Akif Ersoy Üniversitesi, Fen Bilimleri Enstitüsü, Burdur \\ ${ }^{2}$ Burdur Mehmet Akif Ersoy Üniversitesi, Tarım Hayvancılık ve Gıda Araştırmaları Uygulama ve Araştırma Merkezi, Burdur \\ ${ }^{3}$ Burdur Mehmet Akif Ersoy Üniversitesi, Mühendislik Mimarlık Fakültesi, Burdur \\ Geliş Tarihi (Received): 14.01.2021, Kabul Tarihi (Accepted): 12.05.2021 \\ $\square$ Sorumlu Yazar (Corresponding author*): aysgl.cosgun@gmail.com \\ (C) +902482132775 忩 +902482132704
}

\section{ÖZ}

İnce film teknolojisi hemen her sektörde özellikle de elektronik cihaz sektöründe yaygın olarak kullanılmaktadır. İnce filmlerin tercih edilmesindeki en büyük etken üretimine bağlı olarak morfolojik yapısının ayarlanabilir olması, stokiyometrisinin kontrol edilebilmesi ve homojenliğidir. Bu sebeple ince film üretim teknikleri büyük önem arz etmektedir. Bu özellikleri elde etmek için en çok kullanılan yöntem kimyasal buhar biriktirme (KBB) yöntemidir. Bu yönteme bağlı olarak da farklı tasarımlar üzerine çalışmalar yapılmıştır. Bu çalışmada ise kimyasal buhar biriktirme yöntemleri araştırılarak yöntemlerin avantajı ve dezavantajı olduğu parametreler belirlenmiştir.

Anahtar Kelimeler: İnce film, ince film üretim tekniği, kimyasal buhar biriktirme

\section{Chemical Vapor Deposition Method and Types in Thin Film Production}

\begin{abstract}
Thin film technology is widely used in almost every sector. Especially it is used in the electronic device industry. The most important factor in preferring thin films is that their morphological structure can be adjusted depending on their production, their stoichiometry can be controlled and their homogeneity. For this reason, thin film production technique is really important. The most commonly used method to obtain these properties is the chemical vapor deposition method. Depending on this method, studies have been made on different designs. In this study, chemical vapor deposition (CVD) method and its types were investigated and it was aimed to compare the methods.
\end{abstract}

Keywords: Thin film, thin film production technique, chemical vapor deposition

\section{GíRiş}

Elektronik sektörü günümüz ve yakın geleceğin vazgeçilmez bir unsuruyken, ince film teknolojisi, bu sektörün olmazsa olmazlarından bir tanesidir. Ince film teknolojisi, geçmişten günümüze kadar elektronik cihazlar, optik kaplamalar, koruyucu kaplamalar ve dekoratif parçalar yapımında kullanılmıştır. İnce film, geleneksel olarak kullanılan bir malzeme teknolojisi olsa da günümüzde nano malzemelerin geliştirilmesinde önemli bir rol oynamaktadır (Wasa ve ark., 2004). İnce film, ka- lınlığı nanometre mertebesinden bir mikron mertebesine $\left(10^{-6}-10^{-9}\right)$ kadar değişen malzeme tabakaları olarak tanımlanmaktadır. Elektronik cihazların nanometre mertebesinde seçilmesi ile ince film malzemelerdeki gereklilikler de değişmeye başlamıştır. Bir ince filmden istenilen özellikler; kontrol edilebilir kalınlık, iletkenlik, mikro yapısı, saflık vb. gibidir. Ince filmlerden istenilen bu gereksinimler ince film büyütme teknolojisinin gelişimini tetiklemiştir (Crowell, 2003). İnce filmin temel özellikleri genellikle biriktirildiği taban malzemenin cinsinden biriktirme yönteminden ve kalınlığından etkilenmektedir. Bir ince film üretiminin temelinde biriktirilmesi 
istenen malzemenin taban malzeme üzerine taşınması ve orada biriktirilmesi yatmaktadır.

İnce film büyütme teknolojisinde bilinen en eski biriktirme yöntemi elektro-kaplama yöntemidir. Elektrokaplama yönteminde hedef malzeme, çözünmüş metal atomları dolu banyoya daldırılmaktadır. Burada istenilen, elektrik akımı yardımı ile metal atomlarının hedef malzeme üzerinde biriktirilmesidir. Bu biriktirme yöntemi, 19.yüzyılda ucuz olan malzemeleri daha kaliteli göstermek için kullanılmıştır. Ancak günümüzde pahalı malzemeler kullanılarak da aynı yöntem mobilya, otomotiv vb. birçok sektörde kullanılmaktadır. Başka bir biriktirme yöntemi olan püskürtmeyi 1904 yılında Thomas Edison, fonograf kayıtlarının dışına metal bir tabaka uygulamak için kullanmıştır (Holland, 1956). Araştırmacı bilim insanları 1960'lı yıllarda bir malzemenin katmanlarını farklı bir malzemenin taban türüne büyütmek için bir tür ince film buhar biriktirme kullanmışlardır (Waits, 2000).

Günümüzde ince film büyütme teknikleri, buhar fazdan, sıvı fazdan ve katı fazdan büyütme tekniği olarak üç ana başlıkta incelenmektedir. İnce film kaplamasında önemli olan parametreler üretilen malzemenin homojenliği, kalınlık kontrolü, safsızlığın azaltılabilirliği, kontrol edilebilir stokiyometrisi vb. gibidir. Bu parametreleri elde etmeyi mümkün kılan bir diğer ince film üretim yöntemi ise "Kimyasal Buhar Biriktirme (KBB) (Chemical Vapor Deposition (CVD))"'dir. Kimyasal buhar biriktirme yönteminin geliştirilmesi 1880 ve 1890 senelerine dayanmaktadır. Bunu sebebi ilk ampullerdeki karbon filamentlerini güçlendirme istediğidir (Mattox, 2003). KBB yöntemi 1960'lı yıllara kadar kaplama üretiminde kullanılmış olsa da bu yıllardan sonra tozların ve pigmentlerin rafine edilmesi gibi çalışmalarda da kullanılmıştır (Powell ve ark., 1966). İlk uygulamaların çoğu metallerin karbonil işlemiyle saflaştırılması ile ilgilidir. Buna nikelin arıtılması için gerçekleştirilen karbonil işlemi örnek gösterilebilir (Mond ve ark., 1990). Kimyasal buhar biriktirme yönteminin kullanıdığı bir diğer teknoloji mikro-elektro-mekanik sistemler (MEMS)'dir. Bu sistemler silikon wafer üzerine polikristalin silikon filmlerin biriktirilmesiyle oluşturulur ve otomotiv, endüstriyel, askeri, biyoteknoloji vb. gibi geniş bir kullanım alanı vardır (Sniegowski ve De Boer, 2000).

Kimyasal buhar biriktirme kullanılırken uygulanan koşullar süreci ayırt etmektedir. Atmosfer basıncında gerçekleştirilen gaz fazdan biriktirme işlemine Atmosferik Basınçta Kimyasal Buhar Biriktirme (APCVD), biriktirme düşük basınçta gerçekleştiğinde Düşük $\mathrm{Ba}$ sınçlı Kimyasal Buhar Biriktirme (LPCVD), termal reaksiyonlar plazma yardımıyla gerçekleştirildiğinde
Plazma Destekli Kimyasal Buhar Biriktirme (PECVD), taban malzeme üzerinde fotokimyasal bir uyarılma söz konusu olduğunda ise Lazer Destekli Kimyasal Buhar Biriktirme (LECVD), biriktirmede kullanılan öncül gazlar organik bileşikler olduğunda da Metal-Organik Kimyasal Buhar Biriktirme (MOCVD) adını almaktadır.

Karbon nanotüplerin sentezi için birçok yol geliştirilmiş olmasına rağmen kesintisiz lifler halinde birleştirilmesi, işlem sonrası yöntemlerle gerçekleştirilmekteydi bunun üzerine karbon nanotüp liflerinin ve şeritlerin kimyasal buhar biriktirme yöntemi kullanarak doğrudan üretimi sağlandı (Windle ve ark., 2004). AIO ince film üretimi çalışmaları incelendiğinde kimyasal buhar biriktirme ve metal-organik kimyasal buhar biriktirme yöntemi kullanıldığı görülmektedir fakat böylelikle taban malzeme yüksek sıcaklıklara çıkmaktadır. Bunun istenmeyen bir durum olması sebebiyle lazer ve plazma destekli kimyasal buhar biriktirme yöntemi kullanarak daha düşük sıcaklıkta AIO ince film üretilmiştir (Cibert ve ark., 2008). Elektronik cihazlar için önemli bir yeri olan grafenin literatüre bakıldığında tek katmanlı halini üretmenin zor olduğu görülmektedir. Buna rağmen kimyasal buhar biriktirme yöntemi kullanılarak ilk n-katkılı grafen elde edilmiştir (Wei ve ark., 2009). Araştırmacılar yüksek sıcaklıkta kimyasal buhar biriktirme yöntemi kullanarak NbN (Niyobyum Nitrit) ince film üretmiş ve bu yöntemin yüksek kaliteli $\mathrm{NbN}$ epitaksiyel ince katmanların üretimi için umut verici olduğunu savunmuşlardır (Mercier ve ark., 2014). Geçiş metali dikalkojenitler elektronik ve optoelektronik uygulamalar için harika özelliklere sahip 2D (iki boyutlu) malzemelerdir ve ilgiyi üzerine çekmektedir. $2 \mathrm{D}$ ince film üretiminde çeşitli yöntemler kullanılsa da Zn (Çinko) katkılı $\mathrm{MoS}_{2}$ (Molibden Disülfür) ince filmi ilk kez kimyasal buhar biriktirme yöntemi kullanılarak üretilmiş ve yöntemin 2D ince filmler için umut verici olduğu söylenmiştir (Zhang ve ark., 2017). Ayrıca bakır tungstat ince film üretmek için de ilk kez kimyasal buhar biriktirme yöntemi kullanılmıştır. Böylelikle yapılan bu çalışma $\mathrm{W}$ (tungsten) ve $\mathrm{Cu}$ (Bakır) bakımından zengin ayarlanabilir stokiyometriye sahip ince filmler sunmaktadır (Devi, 2018). Oksitleyici ve indirgeyici gazların algılanmasında $\mathrm{CuO}_{2}$ (Bakır Dioksit)'in çeşitli nano yapıları kullanılmasına rağmen seri sensör üretimi zorlayıcı bir faktördür. Bunun üzerine araştırmacılar kimyasal buhar biriktirme yöntemiyle $\mathrm{CuO}_{2}$ filmler üreterek daha kararlı ve tekrarlanabilir sensör elde etmeyi başarmışlardır (Kumar ve ark., 2019). UV fotodetektör üretimi için tek tabakalı bor nitrür üzerine kimyasal buhar biriktirme yöntemi kullanarak GaN (Galyum Nitrit) biriktirilmiş ve sürekli filmler hazırlamak için kimyasal buhar biriktirme yönteminin diğer yöntemlere kıyasla daha ucuz ve basit bir yöntem olduğu rapor edilmiştir (Zhu ve ark., 2020). 
Literatür incelendiğinde yapılan ince film büyütme çaIışmalarında, kimyasal buhar biriktirme yönteminin tercih edildiği görülmektedir. Bu nedenle gün geçtikçe KBB yöntemi bilim insanlarının ilgisini çekmekte ve yoğun bilimsel araştırmaların temelini oluşturmaktadır. KBB yöntemi uygulanarak biriktirilen organik ve inorganik malzemeler, KBB sisteminin farklı tasarımlarının yapımlarına ilham kaynağı olmuştur. Bunun sebebi organik bileşiklerin genellikle kaynama noktası düşük, gaz formda veya çabuk gaz haline geçebilen Sıvı formda ya da erime noktası düşük katı formda bulunmaları ve inorganik bileşiklerin reaksiyon sürelerinin hızlı olmasıdır. KBB sistemleri düşük ve yüksek sıcaklıktaki sistemler, sıcak ve soğuk duvarlı sistemler, alçak ve yüksek basınçlı sistemler olarak sınıflandırılmış ve incelenmiştir. Bu çalışmada KBB yönteminin bağlı olduğu reaksiyon türleri ve reaktör tasarımları anlatılmakta ayrıca ortam koşullarının değiştirilmesiyle ortaya çıkan kimyasal buhar biriktirmenin çeşitli yöntemleri üzerinde durulmaktadır. Buna ek olarak kimyasal buhar biriktirme yöntemlerinin avantajlı ve dezavantajı durumlarından da bahsedilmektedir.

\section{YÖNTEMLER}

\section{Kimyasal Buhar Biriktirme}

Kapalı bir alan içerisinde katı fazdan gaz faza geçen kimyasal bileşik, taşıyıcı gaz tarafından taşınarak taban malzeme üzerine difüzyon yolu ile birikir, bu kimyasal buhar biriktirme (KBB) yöntemi olarak bilinir. Kaplama kalınlığı 10 mikrometreden daha incedir. Malzemenin cinsine bağlı olarak sıcaklık genellikle $1100^{\circ} \mathrm{C}$ 'ye kadar çıkmaktadır. İşlem süresi üretilmek istenen malzemenin kalınlığına bağlıdır. Malzemenin stokiyometrisi, morfolojisi ve kristal yapısı kaplama parametreleri değiştirilerek kontrol edilebilir (Pierson, 1992). Tipik bir KBB sistemi aşağıdaki parçalardan oluşur (Pessoa ve ark., 2014):

1) Gaz kaynakları ve besleme hatları,

2) Gaz girişini ölçmek için kütle akış kontrolörleri,

3) Öncü gazların ayrıştırılması için reaksiyon bölmesi,

4) Taban malzemeyi ısıtmak için bir sistem,

5) Sıcaklık sensörü.

\section{Reaksiyon Mekanizmaları}

Şekil 1'de gösterildiği gibi kimyasal buhar biriktirme mekanizması toplam 7 adımdan oluşmaktadır. Bunlar sırası ile;

1) Sistem içerisine öncül gaz girişi sağlanması,

2) Taşıyıcı gaz ya da vakum yardımıyla bu gazların taban malzeme üzerine taşınması,

3) Reaktif gazların taban malzeme yüzeyine tutunması,

4) Taban malzeme yüzeyinde ince film oluşumu gerçekleşmesi,

5) Reaksiyon sonucu taban malzemeye tutunamayan ve toz halinde kalmış olan reaksiyon ürünlerinin yüzeyden ayrılması,

6) Reaksiyon sonucu atık gazların taşıyıcı gaz ve/veya vakum yardımıyla taşınması,

Atık gazların egzoz sistemi ile reaksiyon odasından uzaklaştırılmasıdır.

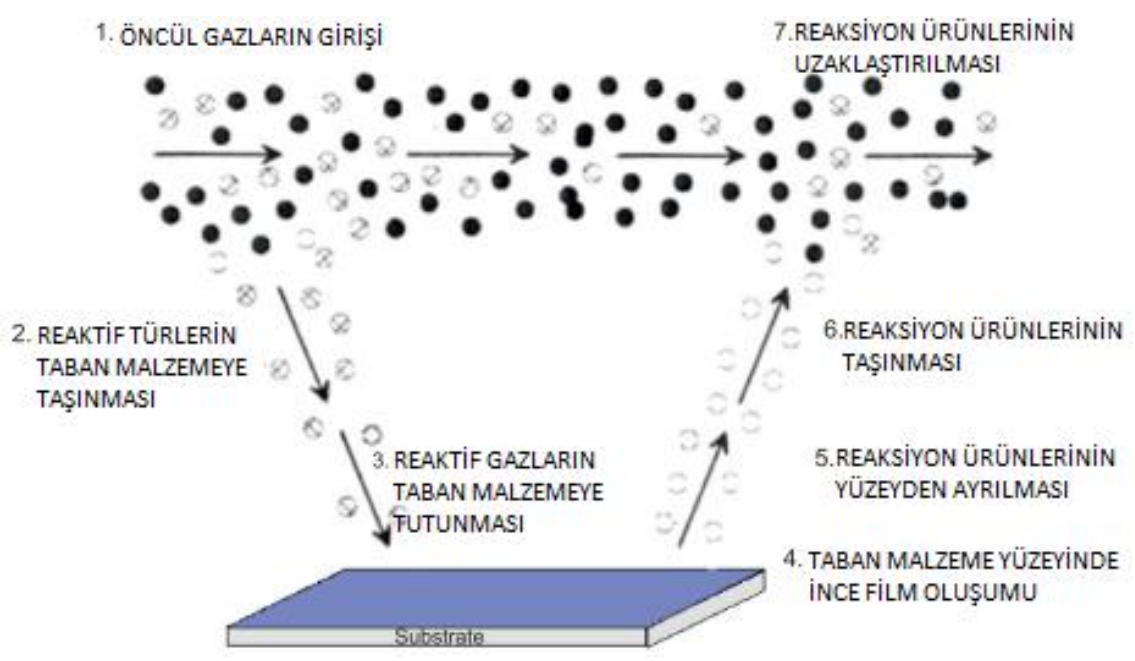

Şekil 1. Kimyasal buhar biriktirme mekanizması (Zou ve ark., 2010) 
Kimyasal buhar biriktirme yöntemiyle ince film biriktirmek için tercih edilen donanım, ince filmde istenilen kaıınlığa, türüne, gaz akışına ve koşullara bağlı olarak gerçekleşen reaksiyona bağlıdır. Bu reaksiyonlar aşağıdaki gibi sıralanmış ve örnek denklemlerle anlatılmıştır (Ohring, 2013):
1) Piroliz
2) Redüksüyon
3) Oksidasyon
4) Tersinir transfer
5) Bileşik oluşumu
6) Oransızlık

\section{Piroliz}

Isıtılmış taban malzeme üzerinde metal-organik gibi bileşiklerin ayrışmasını içeren reaksiyondur. Aşağıdaki denklemde silandan silisyum biriktirmek için $650^{\circ} \mathrm{C}$ 'de gerçekleşen piroliz reaksiyonu verilmiştir:

$$
\mathrm{SiH}_{4(g)} \rightarrow \mathrm{Si}_{(s)}+2 \mathrm{H}_{2(g)}
$$

\section{Redüksüyon}

Oksijen içeren halojenürler ve karbonil halojenürler gibi bileşikleri azaltmak için hidrojen gazının kullanıldığı reaksiyondur. Burada hidrojen gazı hem indirgeme hem de taşıyıcı gaz görevini görür. Pirolizden daha düşük sıcaklıklarda gerçekleşebilmektedir. $300^{\circ} \mathrm{C}$ 'deki inorganik bir bileşik olan molibden hekzaflorür reaksiyonu denklem (2)'de verilmiştir:

$$
M o F_{6(g)}+3 H_{2(g)} \rightarrow M o_{(g)}+6 H F_{(g)}
$$

\section{Oksidasyon}

Genellikle oksijen kullanılarak buhar fazda gerçekleşen kimyasal reaksiyondur. Oksidasyon reaksiyonu hem düşük hem yüksek sıcaklıklarda gerçekleşebilmektedir. Genellikle çeşitli yariletken, iletken ve manyetik film birikimi için kullanılır. En önemli örnekleri aşağıdaki denklemlerdeki gibidir:

$$
\begin{aligned}
& \mathrm{SiH}_{4(g)}+\mathrm{O}_{2(g)} \rightarrow \mathrm{SiO}_{2(s)}+2 \mathrm{H}_{2(g)}\left(450^{\circ} \mathrm{C}\right) \\
& \mathrm{SiCl}_{(g)}+2 \mathrm{H}_{2(g)}+\mathrm{O}_{2(g)} \rightarrow \mathrm{SiO}_{2(g)}+4 \mathrm{HCl}_{(g)}\left(1500^{\circ} \mathrm{C}\right)
\end{aligned}
$$

\section{Tersinir Transfer}

Reaksiyona giren ürünlerin oluşturdukları bileşiklerin sonrasında sisteme ters bir reaksiyona girmesine tersinir reaksiyon denmektedir. Aşağıda ileri reaksiyonun $750^{\circ} \mathrm{C}$ 'de, ters reaksiyonun $850^{\circ} \mathrm{C}$ 'de gerçekleştiği tersinir bir reaksiyon örneği denklemi verilmiştir:

$$
\begin{aligned}
A s_{4(g)} & +A s_{2(g)}+6 G a C l_{(g)} \\
6 H C l_{(g)} & +3 H_{2(g)} \leftrightarrow 6 G a A s_{(s)}
\end{aligned}
$$

\section{Bileşik Oluşumu}

Kimyasal buhar biriktirme yöntemiyle çeşitli reaksiyonlarla birlikte birçok film ve kaplama yapılmaktadır. Bunun için kullanılan bileşiklerin uçucu ve gaz formunda olması yeterlidir. Aşağıda yüksek sıcaklıklarda oluşan bileşikler için reaksiyon örnekleri denklemleri gösterilmektedir:

$$
\begin{aligned}
& \mathrm{SiCl}_{4(g)}+\mathrm{CH}_{4(g)} \rightarrow \mathrm{SiC}_{(s)}+4 \mathrm{HCl}_{(g)} \\
& \mathrm{BF}_{3(g)}+\mathrm{NH}_{3(g)} \rightarrow B N_{(s)}+3 H F_{(g)}
\end{aligned}
$$

\section{Oransızlık}

Bazı reaktan gazlar düşük sıcaklıklarda kararsız olabilmektedir. Oransızlaşım reaksiyonları genellikle metalin uçucu ve yüksek değerli halojenür ile reaksiyona girmesiyle daha kararlı düşük değerli halojenür üretmesini sağlamaktadır. Tipik bir oransızlık reaksiyonu örneğinin denklemi şöyledir:

$$
3 \mathrm{GaCl}_{(g)} \rightarrow 2 \mathrm{Ga}_{(k)}+\mathrm{GaCl}_{3(g)}
$$

Kimyasal buhar biriktirme yöntemi, yarı iletkenler izolatörler, bariyer tabakaları, metaller, silikatlar, süper iletkenler ve organikler dâhil olmak üzere çok çeşitli ince film malzemelerini biriktirmek için kullanılır. Giriş kısmında da bahsedildiği gibi çeşitli malzeme üretimi ve değişen ortam koşulları KBB sisteminin yeni tasarımlarının yapılmasına ve geliştirilmesine sebep olmuştur. Şekil 2 'de gösterilen ince film üretim teknikleri diyagramında kimyasal buhar biriktirme çeşitleri de görülmektedir. 


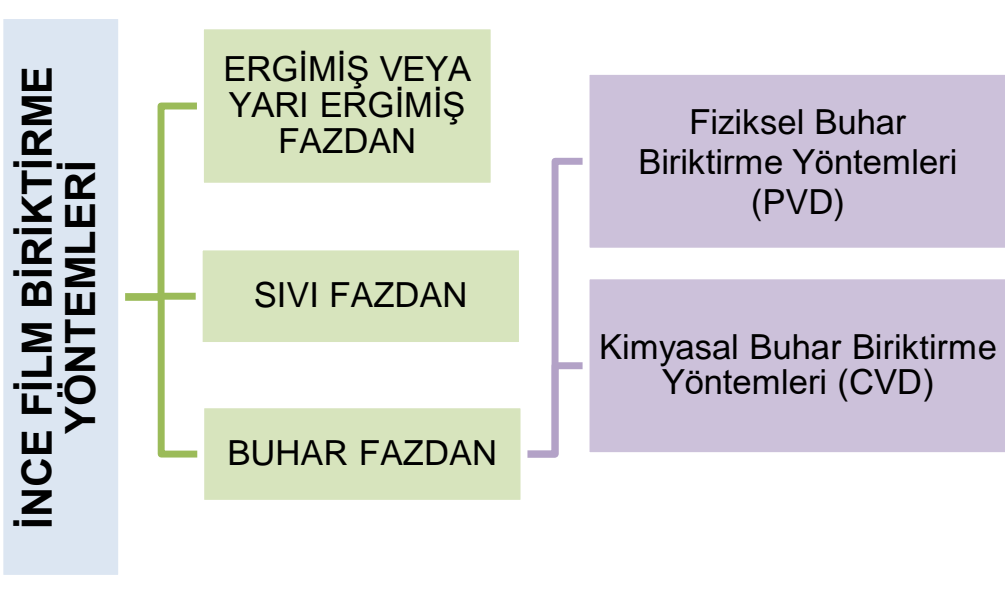

Atmosferik Basınçta

Kimyasal Buhar Biriktirme
(APCVD)
Alçak Basınçlı Kimyasal
Buhar Biriktirme
(LPCVD)

Plazma Destekli Kimyasal

Buhar Biriktirme

(PECVD)

Lazer Destekli Kimyasal

Buhar Biriktirme

(LECVD)

Metal-Organik Kimyasal

Buhar Biriktirme

(MOCVD)

Şekil 2. İnce film biriktirme yöntemleri

\section{Atmosferik Basınçta Kimyasal Buhar Biriktirme (APCVD)}

Bu kimyasal buhar biriktirme yöntemi atmosfer basıncında gerçekleşen bir yöntemdir. Çalışma sıcaklığı aralığı $400-1000^{\circ} \mathrm{C}$ 'dir. Ortamdaki istenmeyen gazlardan kurtulmak için geliştirilmiştir. Tarihte bu yöntemin ilk geliştiricilerinin Lander ve Germer olduğu bilinmektedir
(Hintermann ve ark., 1978). Atmosferik basınçta kimyasal buhar biriktirme reaktörleri, mikro-elektronik teknolojisinde kullanılan Si (Silisyum) ve GaAr (Galyum Arsenik) gibi malzemelerin biriktirilmesi için kullanılmaktadır. Atmosferik basınçta kimyasal buhar biriktirme sistemi Şekil 3'te gösterilmektedir.

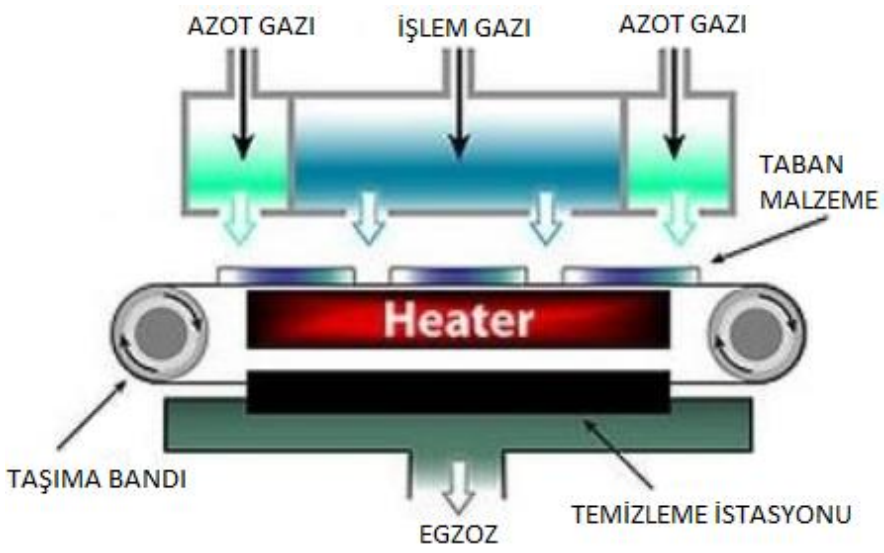

Şekil 3. Atmosferik basınçta kimyasal buhar biriktirme sistemi (Pech-Canul ve ark., 2019)

Atmosferik basınçta kimyasal buhar biriktirmenin difüzyonla sınırlı olmasının yanında reaktör tasarımları ucuz ve yapımı kolaydır. Sürekli çalışma gösterebilirler, vakum gerektirmediği için nispeten ucuzdur (Pierson, 1992). Fakat yüzeyde pürüzlenme olabilir ve üretilen malzeme kalınlığı korunamaz. Atmosferik basınçta kimyasal buhar biriktirme işlemi hem düşük sıcaklıkta hem de yüksek sıcaklıkta gerçekleşebilmektedir.

\section{Düşük Sıcaklıktaki Sistemler}

Si bipolar ve MOS (metal oksit yariletken (metal oxide semiconductor)) entegre devrelerinin imalatında, $\mathrm{SiO}_{2}$ (silisyum dioksit)'in biriktirilmesi önemlidir. $\mathrm{Bir}^{\mathrm{SiO}}{ }_{2}$ ince film biriktirme işlemi için izin verilen en yüksek sıcaklık 400-450 ${ }^{\circ}$ 'dir. Bunun sebebi Si malzemenin bu sıcaklıktan sonra cihaz içerisindeki ara bağlantı için kullanılan $\mathrm{Al}$ 
(alüminyum) metalizasyonu ile tepkimeye girmesidir. Bu sebeple atmosferik basınçta düşük sıcaklıktaki reaktörler tasarlanmıştır (Bohm, 1972).

\section{Yüksek Sıcaklıktaki Sistemler}

Biriktirme yapılırken yüksek sıcaklıklar tercih edilmese de daha kaliteli kaplamalar yüksek sıcaklıkta kimyasal buhar biriktirme yöntemi kullanılarak elde edilmektedir. Bu yalnızca Si için değil yarı iletken malzemeler için de aynıdır. Şekil 7'de gösterilen Soğuk duvarlı reaktör tasarımları Si filmlerinin biriktirilmesinde yaygın bir şekilde kullanılmaktadır. Burada duvarlar hava veya su soğutmalıdır ve malzeme taban tutucu tarafından ısıtılmaktadır (Evans, 1991).

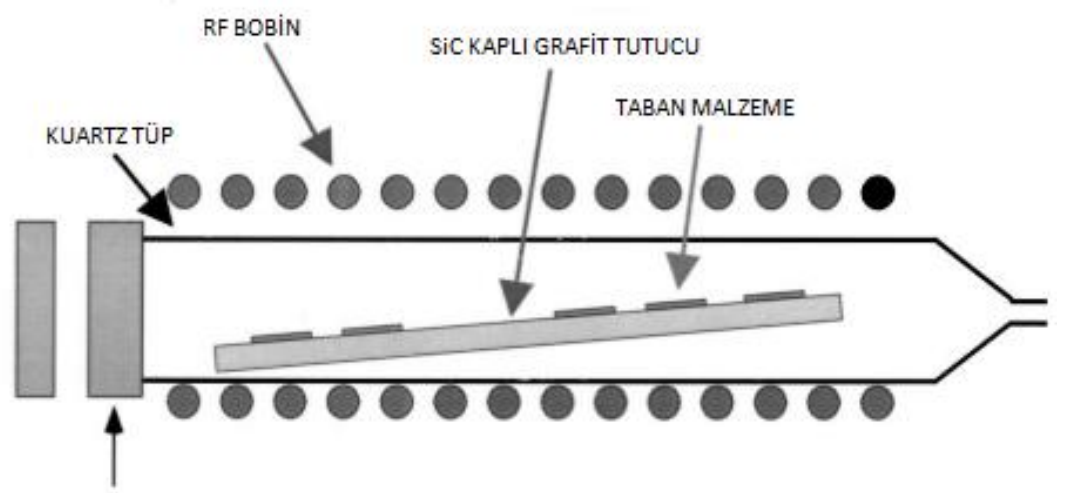

Şekil 4. Yatay soğuk-duvarlı reaktör (Crowell, 2003)

Kimyasal buhar biriktirme reaksiyonlarının çoğu endotermik yani ısıyı emen reaksiyonlardır. Duvarların soğuk kalması sayesinde birikme taban malzemede gerçekleşmekte ve duvarlarda kaplanma olmamaktadır. $\mathrm{Bu}$ sayede temizleme işleminden ve malzeme israfından kaçınılmaktadır (Kobayashi ve Hoshinouchi, 1990).

\section{Alçak Basınçlı Kimyasal Buhar Biriktirme (LPCVD)}

Şekil 5'te gösterilen alçak basınçlı kimyasal buhar biriktirme yönteminde yukarıda anlatılanlarla aynı olacak şekilde taban malzeme üzerine kimyasal reaksiyon sonucu biriktirme yapılmaktadır. Bu sefer taban malzemeler reaktör içerisine yatay pozisyonda yerleştirilmekte ve çok fazla malzeme üretimi yapılabilmektedir. Taban malzemenin altında ve üzerinde ısıtıcıların olması sayesinde ISı homojenliği iyidir böylece biriktirilen malzemenin kalitesi de iyi olmaktadır (Ohring, 2013). Daha düşük reaksiyon sıcaklığına sahip ve gaz akış dinamiğine daha az bağımlı olması nedeni ile atmosferik basınçlı kimyasal biriktirme yönteminden daha avantajıdır.

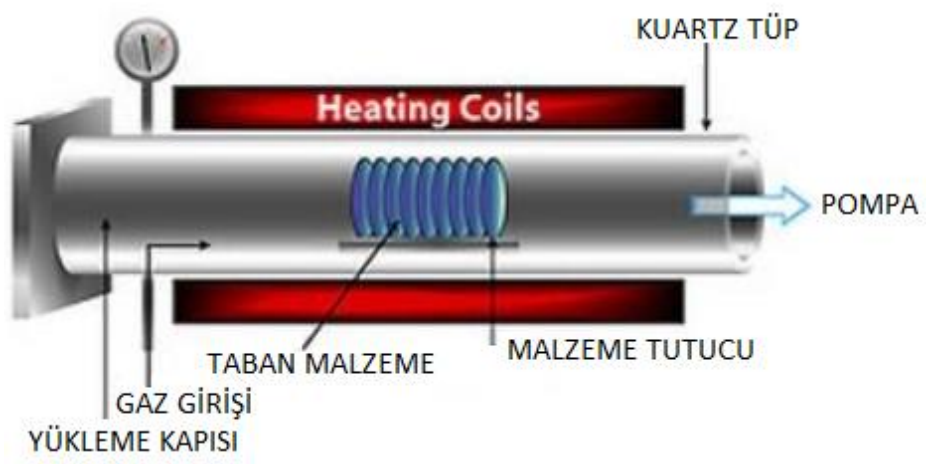

Şekil 5. Alçak basınçta kimyasal buhar biriktirme yöntemi (Pech-Canul ve ark., 2019)

Alçak basınçıı kimyasal buhar biriktirmede kullanılan reaktörlerde işlem 0,5-1 torr basınçta gerçekleşmektedir. Düşük gaz basıncı laminer gaz akışını, reaktanların ve ürünlerin kütle akışını artıımaktadır. Bu reaktör tasarımında gaz moleküllerinin ortalama serbest yolunun art- 
ması, taban malzemelerinin birbirine daha yakın yerleştirilmesine ve verimin artmasına olanak sağlamaktadır (Flinn ve Trojan, 1981).

Bu yatay reaktör tasarımının sıcak duvarlı oluşunun, duvarlarda tortu birikmesine sebep olması bu yüzden sık bir temizliğe intiyaç duyması ve daha çok enerji tüketimi dezavantaj olmaktadır (Kobayashi ve Hoshinouchi, 1990). Buna alternatif olarak dikey tipli reaktör tasarımları kullanılmaktadır.

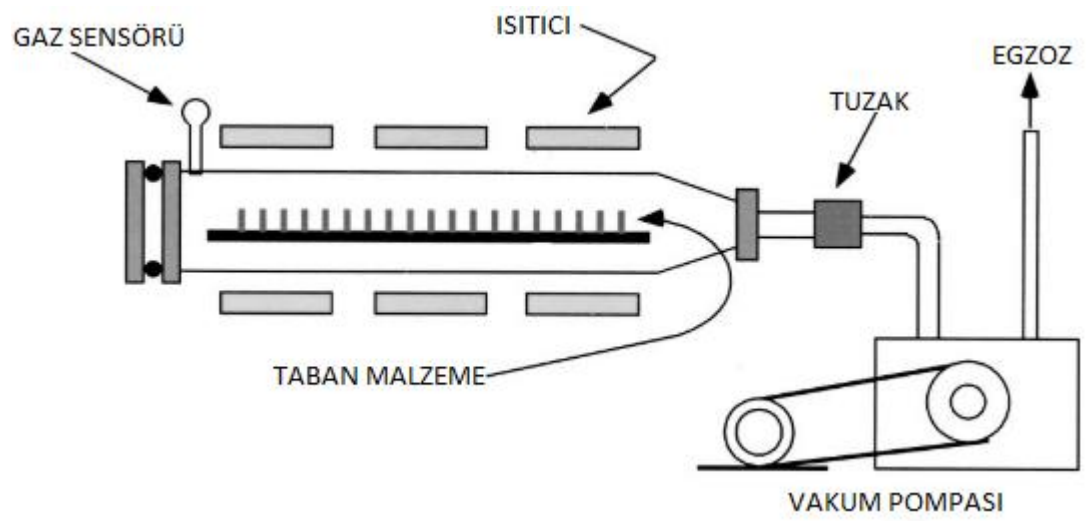

Şekil 6. Alçak basınçta, sıcak-duvarlı reaktör tasarımı (Crowell, 2003)

Düşük basınçlı kimyasal buhar biriktirme yöntemi, yarı iletken teknolojisinde izolatör, amorf ve polikristalin silikon, refrakter metaller ve silisitlerin filmlerini biriktirmek için kullanılmaktadır (Flinn ve Trojan, 1981).

\section{Plazma Destekli Kimyasal Buhar Biriktirme (PECVD)}

Malzeme üretilirken reaktif gazların ayrışması için plazma kullanılmasıyla plazma destekli kimyasal buhar biriktirme yöntemi geliştirilmiştir. Biriktirme gazında plazma oluşturmak için bir radyo frekansı (RF) gücü kullanılmaktadır. Bu şartlarda ortalama elektron enerjileri 1$10 \mathrm{eV}$ arasındadır (Ohring, 2013). Ayrışma için 2-5 eV elektron enerjisi yeterlidir. Atmosfer basıncında biriktirilen malzemelerde stres meydana gelir, RF gücü, biriktirilen filmin stresini değiştirir ve onu sıkıştırmayı sağlar. Bu sistem diğer kimyasal buhar biriktirme yöntemleriyle kıyaslandığında daha düşük sıcaklıklarda çalışabilmektedir. Plazmanın iyon-nötr oranı basınca bağlıdır ve basınç ne kadar düşük olursa bu oran en yüksek düzeyde olacaktır. (Lieberman ve Lichtenberg, 2005).

Plazma-destekli kimyasal buhar biriktirme yönteminde, radyo frekansı sayesinde biri topraklanmış bir diğeri RF gücü kaynaklı iki elektrot arasında meydana gelen elektrik alan, ortama gönderilen gazın elektron ve iyonlara ayrışmasını sağlayarak plazma oluşturur. Burada taban malzeme topraklanmış elektrot üzerine konulur. Plazma içerisindeki elektronların hızı iyonlarınkinden fazladır. Bu sebeple ortamda fazla olan iyonlar, elektrotların etrafında toplanarak perde oluşturur. Burada plazma elektrotlara göre pozitif bir voltaj oluşturur. Elektrotlar kendinden sapma gerilimi kazanır (Pessoa ve ark., 2014). Kendinden sapma oranı elektrot alanlarının oranının karesi ile ters orantılıdır (Lieberman ve Lichtenberg, 2005). Bu yüzden taban malzemelerin koyulduğu topraklanmış elektrotun sapma gerilimi büyüktür. Büyük elektrota göre negatif hale gelmektedir. Negatif yüklü elektrot gerilimi taban malzemelere doğru pozitif yüklü iyonların hızlanmasına sebep olur ve yüzeyde birikecek malzeme için reaksiyonları kolaylaştııır (Pessoa ve ark., 2014). Plazma-destekli kimyasal buhar biriktirme yöntemi Şekil 7 'de gösterilmektedir.

1971 yılında Reinberg, düşük sıcaklıkta üretilen malzemeler için RF destekli reaktör tasarımı yapmıştır. Bu tasarım $\mathrm{Si}_{3} \mathrm{~N}_{4}$ (Silisyum Nitrür) gibi malzemelerin ve optik kaplamaların biriktirilmesinde kullanımaktadır (Martinu ve Poitras 2000). Plazma-destekli kimyasal buhar biriktirme yönteminin kullanılmak istenmesindeki bir diğer etken mikro-elektronik endüstrisindeki cihazların kapsüllenmesinde kullanılan silikon nitrür malzemesinin biriktirilmesidir. Bunun için Şekil 8'de gösterilen reaktör tasarımı yapılmıştır. Burada silikon nitrür, silanın argon plazmasında amonyak ile tepkimeye girmesiyle elde edilir. 500 W'lık güçte $300 \AA$ Aldk'lık biriktirme oranına sahiptir (Ohring, 2013). 


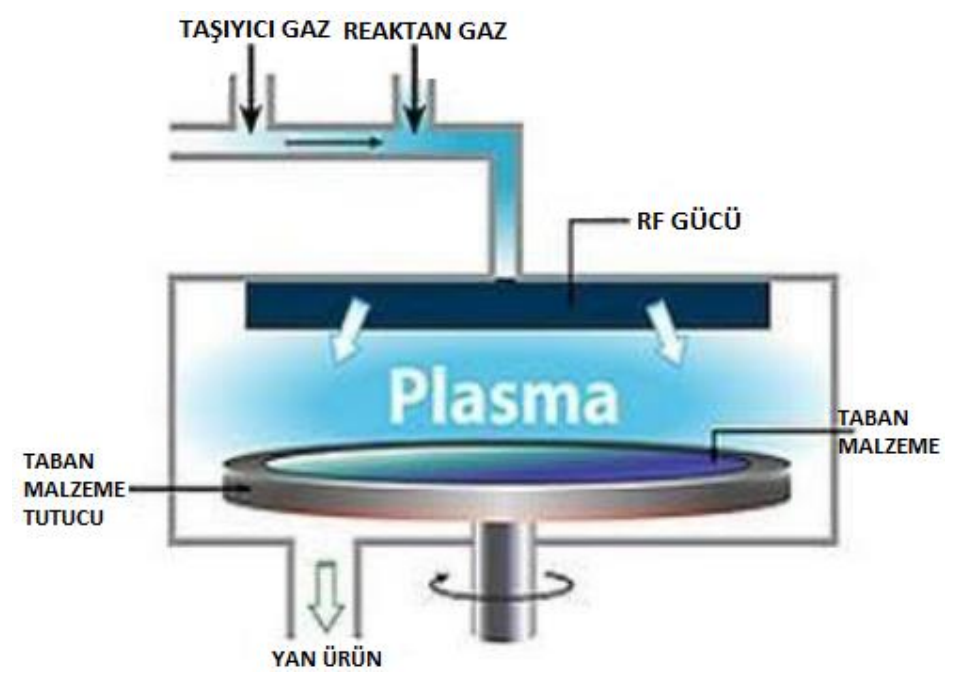

Şekil 7. Plazma-destekli kimyasal buhar biriktirme yöntemi (Karimi ve ark., 2017)

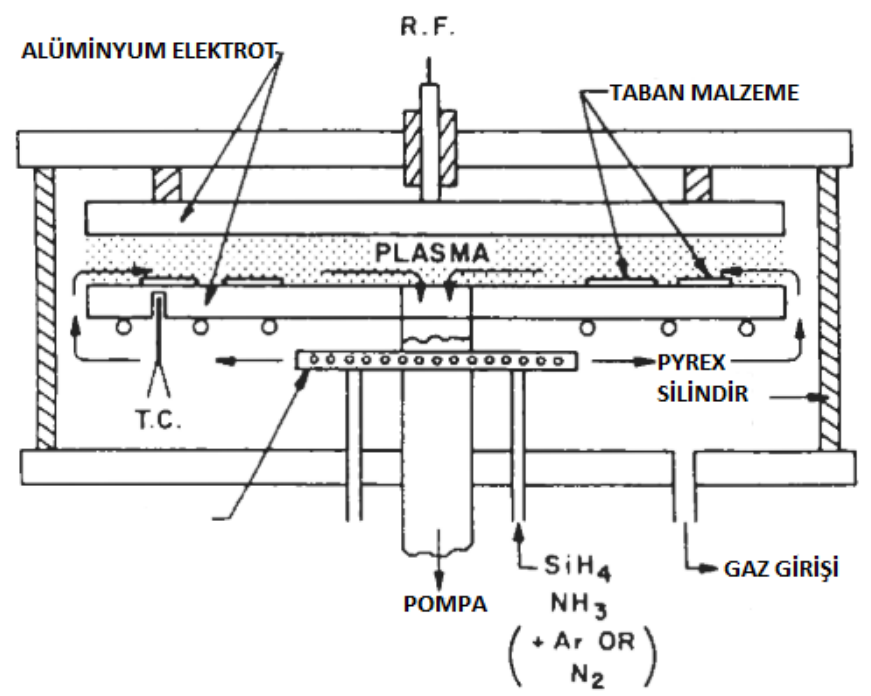

Şekil 8. Plazma-destekli kimyasal biriktirme reaktörü tasarımı (Rand, 1979)

Plazma-destekli kimyasal buhar biriktirme yöntemi kullanılarak diğer kimyasal buhar biriktirme yönteminde inilemeyecek sıcaklıklarda homojen ve neme dayanıklı ince filmler üretilmektedir (Pierson, 1992). Bunun yanında iyon enerjisi dağılımı sırasında yayılan enerjinin kontrollü biriktirmeye engel olması bu yöntemin bir dezavantajı olarak gösterilebilir. Bu enerjinin sebebi, iyonların taban malzemeye doğru akışı sırasındaki hızının, esnek olmayan çarpışmalarıdır (Pessoa ve ark., 2014).

\section{Lazer Destekli Kimyasal Buhar Biriktirme (LECVD)}

Lazer-destekli kimyasal buhar biriktirme yöntemi geleneksel KBB yöntemi ile aynı üretim sistemini ve kimyasını içerir. Lazer yani optik kimyasal işleme, yüksek enerjili bir foton demeti üreterek kimyasal buhar biriktirme yönteminde reaksiyon meydana getirir. Bu yöntem, lazerin taban malzeme tutucusuyla temas ederek ısınması sonucunda termal bir enerji ortaya çıkarmasıyla oluşur. Taban malzeme bölgesel olarak ısıtılmakta ve bu sebeple biriktirme sadece Isıtılan bölgede gerçekleşmektedir (Doppelbauer ve Baeuerle, 1986). Lazer-destekli kimyasal buhar biriktirme yöntemi Şekil 10'da gösterilmektedir.

Şekil 9'da gösterildiği gibi lazer-destekli kimyasal biriktirme yönteminde iki farklı sistem vardır. Bunlar lazerin dalga boyuna ve öncü bileşiklerine göre değişen reaksiyonlarla yönetilen pirolitik ve fotolitik sistemlerdir. 


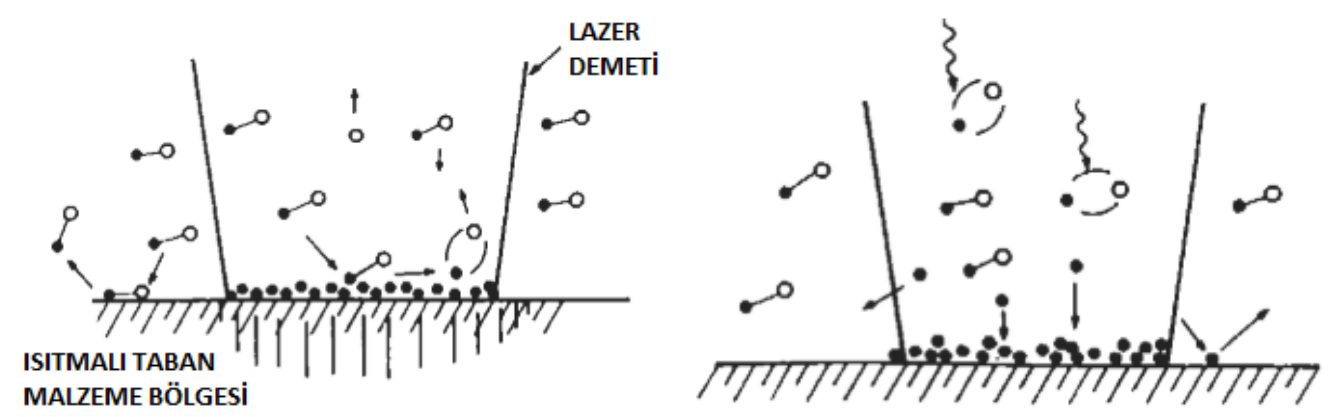

Şekil 9. Lazer-destekli biriktirme sistemleri (Osgood ve Gilgen, 1985)

Pirolitik sistemde lazer, gazları ayrıştırmak ve kimyasal reaksiyonu hızlandırmak için taban malzemeyi ısıtır. Fotolitik sistemde ise moleküller foton enerjisi ile ayrışmaktadır. Bu reaksiyonun başlayabilmesi için gereken dalga boyunun 220 nm'den az olması gerekir bu yüzden kaynak olarak ultraviyole ışık kaynağı seçilir. Her iki yöntem de entegre devre elamanları için metal biriktirmede yeterlidir (Ohring, 2013). Lazer-destekli kimyasal buhar biriktirme yöntemiyle ince filmlerin geniş hacimli yüzeylere kaplanması mümkündür. Fakat bölgesel ısıtma sebebiyle aynı anda çok fazla malzeme birikimi yapılamamaktadır.

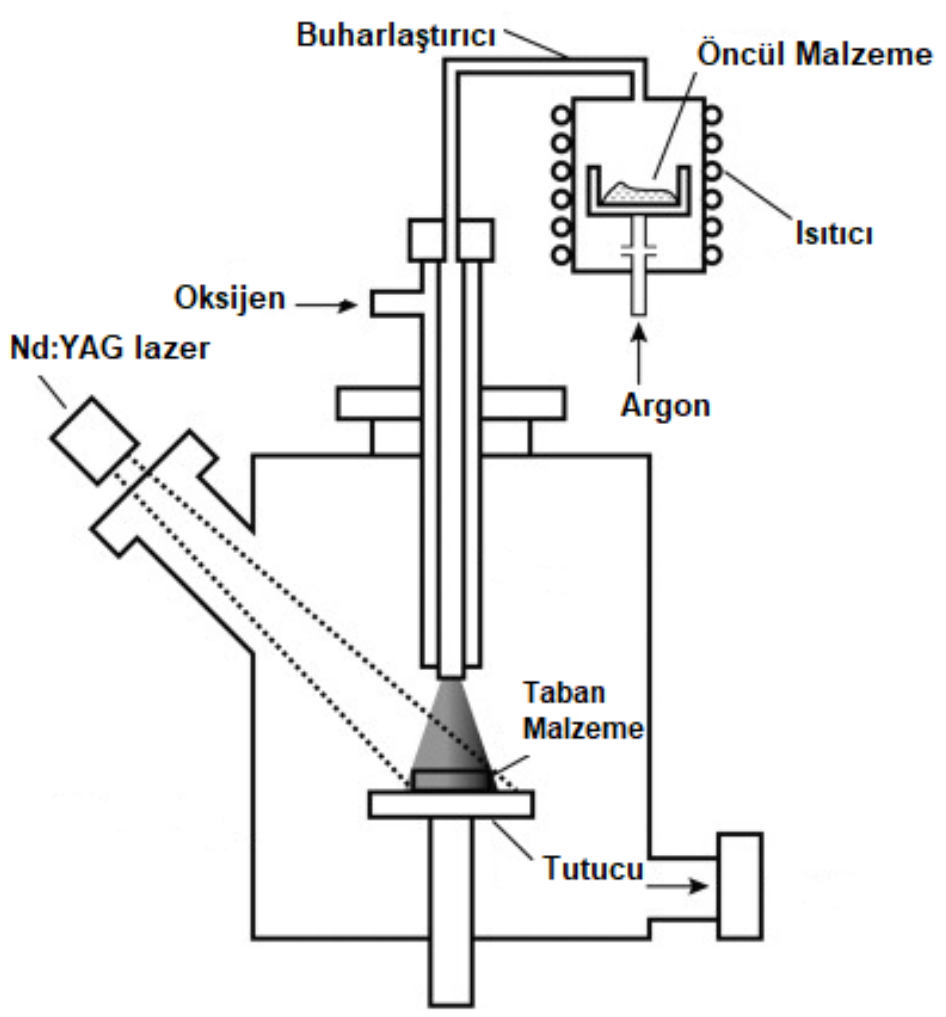

Şekil 10. Lazer-destekli kimyasal buhar biriktirme yöntemi (Zhao ve ark., 2014)

\section{Metal-Organik Kimyasal Buhar Biriktirme (MOCVD)}

Metal-organik kimyasal buhar biriktirme yönteminin ilk kullanımı 1968 yılında safirin üzerine silikon büyütmek için olmuştur (Manasevit, 1968). Günümüzde yariletken ve optoelektronik cihazların epitaksiyel büyütmesinde kullanılmaktadır. Bu yöntemin ayırt edici özelliği biriktirmede kullanılan öncül gazların kimyasal doğasıdır. Trimetil-galyum ve trimetil-indiyum gibi metal-organik bileşikler, periyodik cetvelin 5. grubunda yer alan hidritlerle 
reaksiyona sokularak yarıiletken bileşikler oluşmasını sağlarlar. Metal-organik bileşiklerin en büyük avantajı düşük sıcaklıkta uçucu olmalarıdır (Ohring, 2013).

Metal-organik kimyasal buhar biriktirmede reaktör gazları taban malzeme tutucusuna gelmeden reaksiyona girmezler. Bunun sebebi reaktör seçiminin soğuk-duvar tipli olmasıdır. Reaktör gazı Isıtılan tutucuya gelir ve orada reaksiyona girerek tutucuya difüz eder. Şekil 11 'de metal-organik kimyasal buhar biriktirme yöntemi gösterilmektedir.

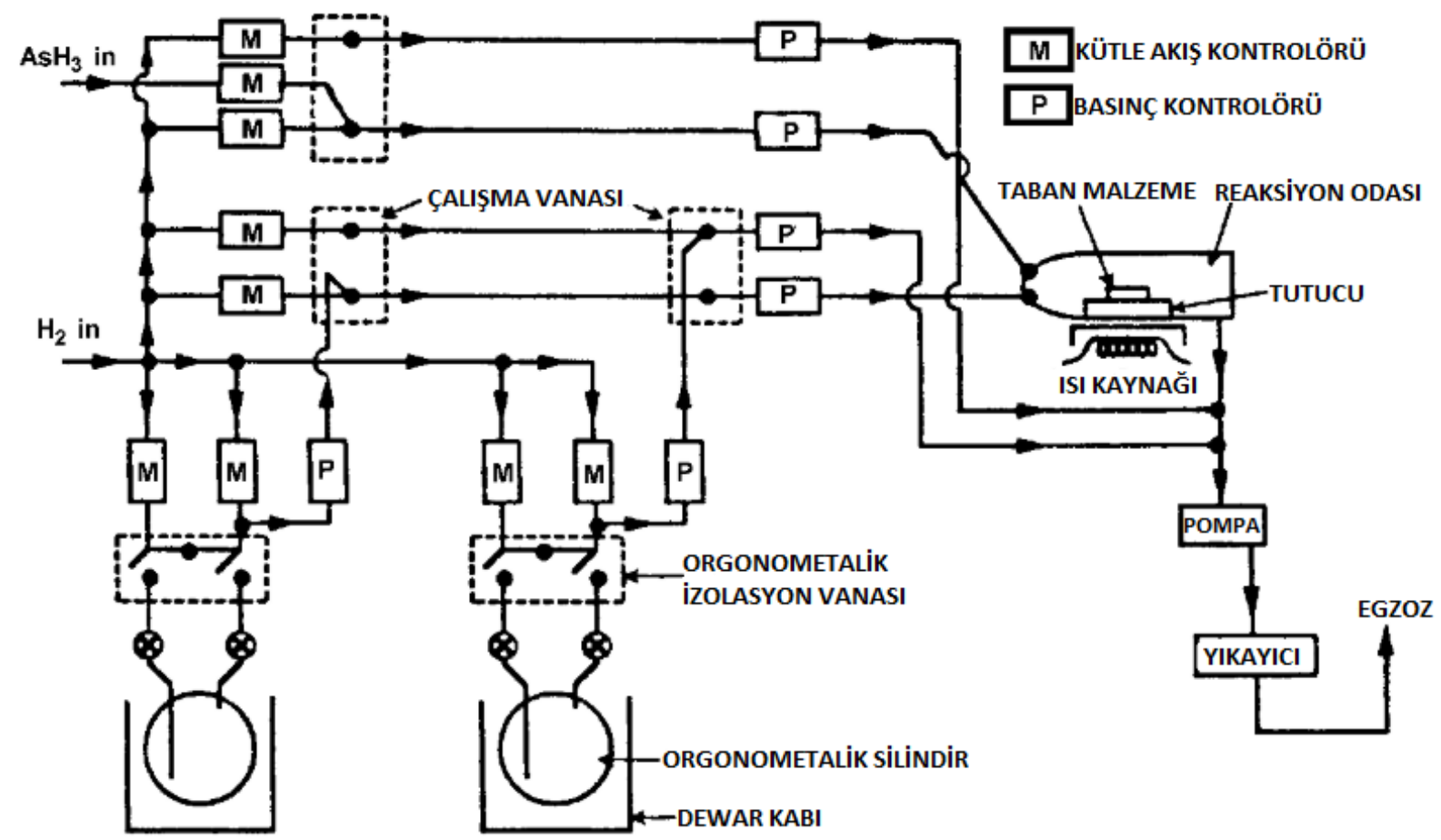

Şekil 11. Metal-organik kimyasal buhar biriktirme yöntemi (Flinn ve Trojan, 1981)

$\mathrm{Bu}$ yöntemde reaksiyonlar $300-800^{\circ} \mathrm{C}$ arasında gerçekleşmektedir. Metal-organik kimyasal buhar biriktirme yönteminde homojen ve yüksek kaliteli malzeme üretimi yapılmaktadır fakat kullanılan öncüllerin maliyeti yüksektir. Ayrıca kullanılan reaktan gazlar zehirli olabilmekte ve havayla temasında yanıcı olma özelliği taşımaktadır (Pierson, 1992).

\section{Reaktör Tasarımları}

Kimyasal buhar biriktirme iki ana fazda incelenir. Bunlardan biri yöntemler kısmında anlatılmış olan reaksiyon kinetiği bir diğeri ise reaktör tasarımıdır. Çalışmanın bu kısmında üç farklı reaktör tasarımından bahsedilecektir.

KBB reaktörleri çeşit çeşit olup, işlenen wafer sayısına, uygulanan basınca, bölme duvarlarının sıcaklığına göre şekillenebilir. Bu reaktör tasarımları aşağıdaki gibidir (Sivaram ve Sivaram, 1995):

- Yatay Tipli Reaktör

- Dikey Tipli Reaktör
- Varil Tipli Reaktör

Yatay Tipli Reaktör

Şekil 12'de gösterilen tasarımda taban malzeme eğimli bir şekilde yerleştirilir böylece aşağı akıştaki gazların tükenmesinin önüne geçmeyi ve gaz akış hızının artmasını hedefler. Buradaki toplam gaz akış hızları yaklaşık 30-70 cm/sn'dir (Eversteyn ve ark., 1970). Bu reaktör tasarımı, çoklu malzeme üretebilmeyi sağlar fakat üretilen malzemeler yeterli homojenliğe ulaşamamaktadır.

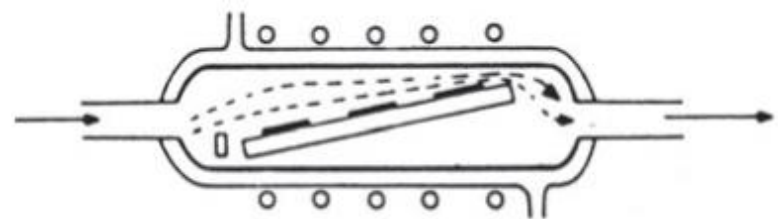

Şekil 12. Yatay tipli reaktör tasarımı (Kern ve Vossen, 2012) 


\section{Dikey Tipli Reaktör}

Bu tasarımda işlem gazı, taban malzeme tutucuların ortasından radyal bir şekilde içeri doğru akar ve yükselir. Yükselen ve tabanda soğuyan bileşik yağmur gibi taban malzemelerin yüzeyine yağarak birikmektedir. Dikey tipli reaktör tasarımı Şekil 13'te gösterilmektedir. Taban malzeme tutucunun yakınındaki radyal gaz akış hızının yaklaşık 5-10 cm/sn olduğu tahmin edilmektedir (Manke ve Donaghey, 1977). Bu reaktör tasarımı yatay tipli reaktör tasarımındaki malzeme homojenliği sorunu için tasarlanmış ve başarılı olmuştur. Üretilen malzemeler kendi içinde ve eşinde homojendir. Fakat bu tasarımda çoklu malzeme üretmek mümkün değildir.

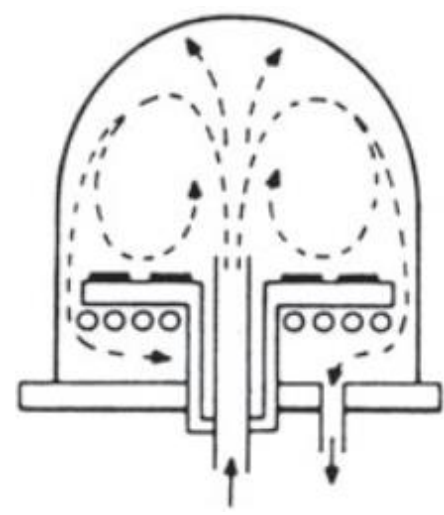

Şekil 13. Dikey tipli reaktör tasarımı (Kern ve Vossen, 2012)

\section{Varil Tipli Reaktör}

Şekil 14'te gösterilen bu ters konik reaktör tasarımında işlem gazı içeri girer ve dolaşır. Buradaki taban malzeme, gaz akış hızını arttırmak için tabana doğru genişlemektedir. Burada işlem gazı, iki gaz püskürtüsüyle aşağı yönde hızlandırılarak reaksiyona girmeden önce yavaşlatııı. Böylece aşağı yönlü gaz akış hızı 40-70 $\mathrm{cm} / \mathrm{sn}$ hızındayken taban malzeme tutucu üzerinde 10$20 \mathrm{~cm} / \mathrm{sn}$ 'dir (Corboy ve Pagliaro, 1983). Bu tasarımda aynı anda çoklu malzeme üretimi sağlanmaktadır fakat dezavantajı ise ISı homojenizasyonunun iyi olmamasıdır.

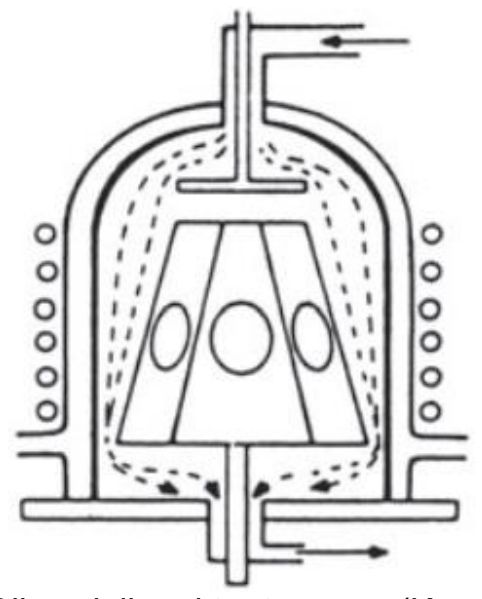

Şekil 14. Dikey tipli reaktör tasarımı (Kern ve Vossen, 2012)

\section{SONUÇLAR}

Kimyasal buhar biriktirme yönteminde özetle belirli bir sıcaklığa, elektrik alana ya da lazer uygulamasına maruz kalan malzeme faz değiştirmekte ve taşıyıcı bir gazla birlikte taban malzeme üzerine taşınmaktadır. Taşınan malzeme sıcaklık farkından kaynaklı olarak taban malzeme üzerine difüz etmektedir.

Kimyasal buhar biriktirme yönteminin çeşitleri incelendiğinde atmosferik basınçta kimyasal buhar biriktirme yönteminin vakum gerektirmediği için daha ucuz bir yöntem olduğu fakat kalınlık kontrolünün sağlanamadığı görülmektedir. Alçak basınçlı kimyasal buhar biriktirme yöntemi incelendiğinde ise taban malzeme üzerine ve altına yerleştirilen ısıtıcılar sayesinde ısının homojen bir şekilde yayılması avantaj olarak görülürken duvarlarda çok fazla tortu birikmesinden kaynaklanan temizlik intiyacı ve fazla enerjiye gerek duyulması bir dezavantaj olarak görülmektedir. Plazma destekli kimyasal buhar biriktirme yöntemi incelendiğinde diğer yöntemlerle inilemeyen sıcaklıklarda homojen malzeme üretmenin mümkün olduğu fakat plazma oluşturmak için harcanan enerji bir dezavantaj olarak görülmektedir. Lazer destekli kimyasal buhar biriktirme yönteminde ise bölgesel üretim yapmak mümkündür fakat bu sebeple aynı anda çok malzeme üretmek mümkün değildir. Metal-organik kimyasal buhar biriktirme yöntemi incelendiğinde homojen ve kaliteli malzeme üretmenin mümkün olması bir avantajdır fakat bunun yanında kullanılan malzemelerin maliyetinin çok olması ve reaktan gazlarının zehirli olma intimali dezavantajları olarak gösterilmektedir.

Özetle kimyasal buhar biriktirme yöntemi, yüksek saflıkta malzeme biriktirme, yüksek seviyelerde vakum gerektirmeme, kontrollü yüzey morfolojisiyle birlikte kompleks heteroyapılar elde edebilme, buna ek olarak sayıca 
fazla malzeme üretimi gibi birçok avantaja sahiptir. Bunun yanında kullanılan bazı öncülerin maliyetli olması, yerinde izlemenin mümkün olmaması, fazla miktarda toksik ve yanıcı gaz kullanımı gibi dezavantajları da bulunmaktadır. Görüldüğü gibi her sistemin avantajları ve dezavantajları vardır. Bir sistemi en iyi yapan şey ise analizinin net bir şekilde yapılarak intiyaca uygun bir tasarım oluşturulmasından geçmektedir. Araştırmacıların gerçekleştirecekleri bilimsel çalışmalarda intiyaç duydukları parametreleri belirlemelerinin ve analizlerini yapmalarının ardından bu derleme makalede belirtilen detayları dikkate aldıkları takdirde daha iyi bir sonuç elde edecekleri üretim sistemini belirleyeceklerine inancımız tamdır.

\section{KAYNAKLAR}

Bohm, J., R. A. Laudise (1972). In The Growth of Single Crystals. Kristall Und Technik, 7(1-3): K17-K18.

Cibert, C., Hidalgo, H., Champeaux, C., Tristant, P., Tixier, C., Desmaison, J., Catherinot, A. (2008). Properties of aluminum oxide thin films deposited by pulsed laser deposition and plasma enhanced chemical vapor deposition. Thin Solid Films 516: 1290-1296.

Corboy, J. F., Pagliaro, R. (1983). Investigation of The Factors That Influence The Deposit/Etch Balance In A RadiantHeated Silicon Epitaxial Reactor. R.C.A. Review, 44(2): 231-249.

Crowell, J. E. (2003). Chemical methods of thin film deposition: Chemical vapor deposition, atomic layer deposition, and related technologies. Journal of Vacuum Science \& Technology A: Vacuum, Surfaces, and Films 21(5): 88-95.

Devi A., Beranek, R., Eichberger, R., Toroker, M.C., Nagli, M., Mitoraj, M., Friedrich, D., Müller, S., Hirst, J., Schütz, H.M. Becker, H., Rogalla, D., Cwick, S., Sadlo, A., Mai, L., Reyes, Q.M, Peeters, D. (2018). CVD-Grown Copper Tungstate Thin Films For Solar Water Splitting. Journal of Materials Chemistry A 6: 10206-10216.

Doppelbauer, J., Baeuerle, D. (1986). Kinetic Studies of Pyrolytic Laser-Induced Chemical Processes. 1986 Editions de Physique, Conference Proceedings 53-56.

Evans, G. H. (1991). Design and Verification of Nearly Ideal Flow and Heat Transfer in a Rotating Disk Chemical Vapor Deposition Reactor. Journal of the Electrochemical Society, 138(6): 1806-1816.

Eversteyn, F. C., Severin, P. J. W., Brekel, C. H. J. V. D., Peek, H. L. (1970). A Stagnant Layer Model for the Epitaxial Growth of Silicon from Silane in a Horizontal Reactor. Journal of the Electrochemical Society 117(7): 1-925.

Flinn, R. A., Trojan, P. K. (1981). Engineering Materials and Their Applications. In Manufacturing Technology. CRC Press, 90-123.

Hintermann, H. E., Perry, A. J., Horvath, E. (1978). Chemical vapour deposition applied in tribology. Wear 47(2): 407415.

Holland, L. (1956). A New Apparatus for Cathodic Sputtering. Nature 177: 1229.
Karimi, M., Ghasemi, A., Mirkiani, S., Moosavi, S. M., Moosavi Basri, S. M., Hamblin, M. R. (2017). Carbon Nanotubes in Drug and Gene Delivery. In Carbon Nanotubes in Drug and Gene Delivery. IOP Publishing.

Kern, W., Vossen, J. L. (2012). Thin Film Processes II. In Thin Film Processes II. Elsevier, 1-866.

Kobayashi, M., Hoshinouchi, S. (1990). Introduction to chemical vapor deposition. Boshoku Gijutsu, 39(10): 576581.

Kumar, J.R., Vivek, S., Jyoti, S., Sushobhan, A., Navakanta, B. (2019). CVD Grown Cuprous Oxide Thin Film Based High Performance Chemiresistive Ammonia Gas Sensors. IEEE Sensors Journal 19: 11759-11766.

Lieberman, M. A., Lichtenberg, A. J. (2005). Principles of Plasma Discharges and Materials Processing: Second Edition. In Principles of Plasma Discharges and Materials Processing: Second Edition. John Wiley and Sons, 1-757.

Manasevit, H. M. (1968). Single-crystal gallium arsenide on insulating substrates. Applied Physics Letters 12(4): 156159.

Manke, C. W., Donaghey, L. F. (1977). Analysis of Transport Processes. In Vertical Cylinder Epitaxy Reactors. Journal of the Electrochemical Society, 77-5: 151-165.

Martinu, L., Poitras, D. (2000). Plasma deposition of optical films and coatings: A review. Journal of Vacuum Science \& Technology A: Vacuum, Surfaces, and Films. 18(6): 2619_ 2645.

Mattox, D. M. (2003). The Foundations of Vacuum Coating Technology. In The Foundations of Vacuum Coating Technology. The Foundations of Vacuum Coating Technology, Elsevier, 1-150.

Mercier, F., Coindeau, S., Lay, S., Crisci, A., Benz, M., Encinas, T., Boichot, R., Mantoux, A., Jimenez, C., Weiss, F., Blanquet, E. (2014). Niobium nitride thin films deposited by high temperature chemical vapor deposition. Surface and Coatings Technolgy 260: 126-132.

Mond, L., Langer, C., Quincke, F. (1990). Action of Carbon Monoxide on Nickel. In Journal of Organometallic Chemistry 57: 749-753.

Ohring, M. (2013). The Materials Science of Thin Films. In The Materials Science of Thin Films. Elsevier, 1-704.

Osgood, R. M., Gilgen, H. H. (1985). Laser Direct Writing of Materials. Annual Review of Materials Science 15(1): 549_ 576.

Pech-Canul, M. I., Valdez Rodríguez, S., González, L. A., Ravindra, N. M. (2019). Emerging Opportunities and Future Directions. In Semiconductors. Springer International Publishing 575-583.

Pessoa, R. S., Fraga, M. A., Santos, L. V., Galvão, N. K. A. M., Maciel, H. S., Massi, M. (2014). Plasma-assisted techniques for growing hard nanostructured coatings: An overview. Anti-Abrasive Nanocoatings: Current and Future Applications 456-479.

Pierson, H. O. (1992). The Chemistry of Cvd. In Handbook of Chemical Vapor Deposition. Elsevier, 51-80.

Powell, C. F., Oxley, J. H., Blocher, J. M., Klerer, J. (1966). Vapor Deposition. Journal of The Electrochemical Society 113(10): 266C.

Rand, M. J. (1979). Plasma-Promoted Deposition of Thin Inorganic Films. Journal of Vacuum Science and Technology , 16(2): 420-427. 
Sivaram, S., Sivaram, S. (1995). Reactor Design for Thermal CVD. Chemical Vapor Deposition, 94-118.

Sniegowski, J. J., De Boer, M. P. (2000). IC-compatible polysilicon surface micromachining. Annual Review of Materials Science, 30: 299-333.

Waits, R. K. (2000). Evolution of integrated-circuit vacuum processes: 1959-1975. Journal of Vacuum Science and Technology A: Vacuum, Surfaces, and Films 19(1): 388388.

Wasa, K., Kitabatake, M., Adachi, H., Wasa, K., Kitabatake, M., Adachi, H. (2004). Thin Film Materials and Devices. Thin Film Materials Technology 1-16.

Wei, D., Liu, Y., Wang, Y., Zhang, H., Huang, H., Yu, G. (2009). Synthesis of N-Doped Graphene by Chemical Vapor Deposition and Its Electrical Properties. Nano Letters 9: 1752-1758.

Windle, A.H., Li, Y., Kinloch, I.A. (2004). Direct Spinning of Carbon Nanotube Fibers from Chemical Vapor Deposition Synthesis. Science 304: 276-278.
Zhao, P., Huang, Z., Mao, Y., Wang, Y., Takashi, G. (2014). Preparation of (100)-oriented $\mathrm{CeO} 2$ film on (100) $\mathrm{MgO}$ single crystal substrate by laser chemical vapor deposition using solid precursor. Ceramics International 40(10): 15919-15923.

Zhang, S.X., Fertig, H.A., Werbianskyj, M., Starr, M., Losovyj, Y., Li, Z., Park, K., Liu, H.M., Xu, E.Z. (2017). P-type transition-metal doping of large-area MoS2 thin films grown by chemical vapor deposition. Nanoscale 9: 3576-3584.

Zhu, W.H., Si, J.W., Zhang, L., Li, T., Song, W.Q., Zhou, Y.T., Yu, J.H., Chen, R., Feng, Y.X., Wang, L.C. (2020). Growth of $\mathrm{GaN}$ on monolayer hexagonal boron nitride by chemical vapor deposition for ultraviolet photodetectors. Semiconductor Science and Technology 35: 125025.

Zou, C. W., Wang, H. J., Li, M., Yu, Y. F., Liu, C. S., Guo, L. P., \& Fu, D. J. (2010). Characterization and properties of TiN-containing amorphous Ti-Si-N nanocomposite coatings prepared by arc assisted middle frequency magnetron sputtering. Vacuum 84(6): 817-822. 